\title{
Effect of bleeding method and low voltage electrical stimulation on meat quality of ostriches
}

\author{
L.C. Hoffman ${ }^{1 \#}$, S.W.P. Cloete ${ }^{1,2}$, S.J. van Schalkwyk ${ }^{1}$ and S.St.C. Botha ${ }^{1}$ \\ ${ }^{1}$ Department of Animal Sciences, Private Bag X1, Matieland 7602, South Africa \\ ${ }^{2}$ Institute of Animal Production: Elsenburg, Private Bag X1, Elsenburg 7607, South Africa
}

\begin{abstract}
The effect on ostrich muscle quality of an additional thoracic stick (TS) to the normal ventral throat slit to bleed ostriches after electrical stunning was evaluated. The additional TS had no negative or positive effect on the drip loss, cooking loss, colour or $\mathrm{pH}$ and temperature readings of the fillet (Muscularis iliofibularis), big drum (M. gastrocnemius, pars interna) and inside loin (M. iliotibialis cranialis). None the less, personal observations would recommend the use of TS due to ethical considerations. An early post mortem low voltage electrical stimulation (ES) of the carcasses also had no influence on the cooking loss, drip loss and colour of these muscles. Electrical stimulation did result in a lower $\mathrm{pH}_{45}$ in both the fillet and big drum muscles. However, after $24 \mathrm{~h}$ the $\mathrm{pH}$ of the muscles did not differ. Electrical stimulation also caused elevated initial muscle temperatures, although this effect was only temporary due to the efficient cooling mechanism used in the abattoir. Electrical stimulation also had no effect on the Warner Bratzler shear force values in the fillet. It can be concluded that low voltage ES has no advantage pertaining to physical quality characteristics of importance in an ostrich abattoir.
\end{abstract}

Keywords: electrical stimulation, gender, ostrich, $\mathrm{pH}$, thoracic sticking (TS), exsanguination, colour

\#Corresponding author. E-mail: lch@sun.ac.za

\section{Introduction}

Electrical stimulation (ES) is usually applied in the red meat industry to cattle and sheep; predominately to inhibit the possibility of cold shortening when the carcasses are cooled rapidly (Wu et al., 1985; Stiffler et al., 1986; Taylor \& Tantikov, 1992) or to enhance the activity of the enzyme systems (low $\mathrm{pH}$ at a high temperature) - a procedure frequently used when meat will be frozen soon after rigor mortis (Simmons et al., 2008). Muscles are at risk of cold shortening in pre-rigor muscles if muscle temperature falls below $10{ }^{\circ} \mathrm{C}$ while the $\mathrm{pH}$ is still high $(\mathrm{pH}>6.0$ - 6.2) and an adequate amount of energy (ATP) is present (Pearson \& Young, 1989). Electrical stimulation shortens the time to the onset of rigor mortis, accelerates post mortem glycolysis and lowers the $\mathrm{pH}$ of the musculature (Lawrie, 1998; Simmons et al., 2008). Therefore, it contributes to the reduction in the risk of cold shortening. As reviewed by Hwang et al. (2003) and Simmons et al. (2008) the proposed areas by which electrical stimulation elicits changes in post mortem muscles, include (1) prevention of cold shortening by ensuring the development of rigor mortis under optimal conditions, (2) physical disruption of the muscle fibres, and (3) acceleration of proteolysis. Rosenveld et al. (2008) also found that electrical stimulation conferred a degree of protection to toughening (and adverse conditions that may cause protein denaturation) when the muscles are still at a high temperature - this may be an important phenomenon as pertaining to ostrich muscles that have been shown to enter rigor mortis rapidly at high temperatures (Botha et al., 2004a).

However, electrical stimulation does not necessarily improve overall meat quality, since water-binding capacity and colour stability may be negatively affected (Wiklund et al., 2001; Simmons et al., 2008). Electrical stimulation contributes to reduce water-binding capacity in beef by accelerating $\mathrm{pH}$ decline, though it was shown that the magnitude of the effect depends on chilling rate (den Hertog-Meischke et al., 1997). However, McGlone et al. (2005) and Rosenvold et al. (2008) found that the drip loss was correlated to tenderisation post mortem rather than muscle temperature pre rigor. Electrical stimulation also affects meat colour in beef, although again the extent of the changes will depend on the chilling rate but also on the observed muscle (Hector et al., 1992; Martin et al., 1983; Sleper et al., 1983). In general, electrical stimulation resulted in a lighter colour because of increased protein denaturation and myofibrillar lattice 
shrinkage (Offer et al., 1983). At 24 h post mortem electrically stimulated beef is typically also redder in colour (Sleper et al., 1983).

The different anatomical ostrich muscles are not equally susceptible to the risk of cold shortening. It was suggested by Sales \& Mellet (1996) that the risk of cold shortening would be reduced in the M. iliofibularis since it reached a $\mathrm{pH}$ of less than 6.20 at approximately $34 \mathrm{~min}$ after slaughter. The apparent ultimate $\mathrm{pH}$ of $6.00 \pm 0.087$ was reached rapidly after $2 \mathrm{~h}$ post mortem in the $M$. iliofibularis, and at $6 \mathrm{~h}$ post mortem in the $M$. gastrocnemius, pars interna $(6.12 \pm 0.056)$. It was thus concluded by Sales \& Mellet (1996) that there might be a risk of cold shortening in the M. gastrocnemius, pars interna if this muscle is to be separated from the carcass at 30 - 45 min post mortem, but not in the M. iliofibularis.

After stunning ostriches are bled by means of a complete ventral cut to the neck and/or by thoracic sticking (TS). Although no research has been reported on the effectiveness of these two methods, personal observation seems to indicate that better and faster bleed-out is obtained when both the neck cut and thoracic stick are performed. In a pilot investigation where the two bleeding methods were applied, 10 ostriches subjected to ventral throat cut alone had an average ( \pm s.d.) bleed-out percentage (defined as weight of blood expressed as a percentage of live weight) of $2.8 \pm 1.03 \%$. When the ventral cut was combined with thoracic sticking, the bleed-out was $3.3 \pm 0.34 \%$. The means could not be proven to differ significantly $(\mathrm{P}=0.16)$, but the magnitude and direction of the absolute difference seem to warrant further investigation.

In some South African abattoirs, electrically stimulation is applied to the carcasses during the bleeding phase. It is postulated that this helps with the bleed-out and thereby increasing the shelf life of the meat (by reducing the amount of residual blood in the meat). However, no research has yet been reported to substantiate this claim. Morris et al. (1995) noted that ES 45 min post mortem had no influence on ostrich muscle $\mathrm{pH}$ or temperature decline. However, we now know that ostrich muscle $\mathrm{pH}$ undergoes a very rapid decline post mortem (Botha et al., 2004a; b; 2008) and if any benefit was to be derived from ES it would most probably only be of value if it was applied as early post mortem as possible.

The present investigation was therefore initiated to quantify the effect of the method of bleed-out and the use of low voltage ES on the physical meat quality of ostrich steaks.

\section{Materials and Methods}

The experimental animals were 60 slaughter ostriches drawn at random from the progeny of the commercial ostrich breeding flock maintained on the Oudtshoorn Research Farm (ORF) near Oudtshoorn, South Africa. The environment and the flock are well documented in the literature (Van Schalkwyk et al., 1996). The experimental animals were grown out in a single flock under feedlot conditions, where they received a commercial diet containing $11.5 \mathrm{MJ}$ metabolizable energy $/ \mathrm{kg}, 150 \mathrm{~g}$ crude protein $/ \mathrm{kg}, 8 \mathrm{~g}$ calcium $/ \mathrm{kg}$ and $3 \mathrm{~g}$ phosphorus $/ \mathrm{kg}$ feed on an ad libitum basis. After the growing out phase, the experimental animals were slaughtered at a commercial ostrich abattoir in Oudtshoorn at an average ( \pm s.d.) age of $251 \pm 31$ days. All animals were transported to the abattoir at noon of the day prior to slaughter. After spending the night in lairage, all animals were slaughtered at random early during the following morning. All animals had unrestricted access to clean drinking water throughout the experimental period. Slaughter and dressing were done according to standard South African procedures at an export abattoir approved by the European Union (Hoffman, 2005). Upon slaughter, the ostriches were randomly allocated to one of four groups, the treatments being thoracic sticking (neck exsanguination as control vs. neck exsanguination as well as thoracic sticking) and electrical stimulation (no stimulation as control vs. stimulation). After electrical stunning $(110 \mathrm{~V}, 50 \mathrm{~Hz}, 0.9 \mathrm{~A}, 30 \mathrm{~s})$ the birds were hung by the toe and bled by means of a complete ventral cut to the neck. Thoracic sticking (TS) involved the puncturing of the aorta with a sharp knife. Electrical stimulation (ES) involved passing a current of $50 \mathrm{~V}$ (square wave form, $17 \mathrm{~Hz}, 5 \mathrm{~ms}$ between pulses) at $200 \mathrm{~mA}$ for $3 \mathrm{~s}$ on and $3 \mathrm{~s}$ off for $1 \mathrm{~min}$ (electrodes coupled to the bleeding trough which touches the neck of the bird and to the toe) to the carcasses during the bleeding phase. Each of the four possible treatment combinations was represented by 15 animals.

All animals were weighed immediately prior to slaughter (live weight). Due to the design of the abattoir, it was not possible to weigh the birds after the bleeding and ES procedures. After evisceration the thighs of each bird were removed from the carcass and weighed. The $\mathrm{pH}$ and temperature within the fan fillet (Muscularis iliofibularis) and big drum (M. gastrocnemius, pars interna) muscles of the right drumstick of all individuals were recorded 45 min after exsanguination and after having been kept in a refrigerated 
room for $26.5 \mathrm{~h}$. A handheld Crison $\mathrm{pH} / \mathrm{mV}-506 \mathrm{pH}$ meter equipped with a glass electrode was used to determine $\mathrm{pH}$ and temperature, as described by Honikel (1998). Intra-muscular $\mathrm{pH}$ and temperature profiles were studied more intensively in both muscles of 32 individuals (eight birds per group) selected randomly to assess responses in $\mathrm{pH}$ and temperature. These recordings were made 60 min post mortem in this case, and again 140, 260, 380, 440, 500, 560, 680, 860 and 1440 (24 h) min, respectively. As these birds were slaughtered and processed under the same conditions, it was not deemed necessary to correct $\mathrm{pH}$ for temperature. The fillet, inside loin (M. iliotibialis cranialis) and big drum muscles were dissected from the left thighs of 47 individual carcasses $(>26.5 \mathrm{~h}$ post-mortem) and transported in insulated cooler boxes $\left(<8{ }^{\circ} \mathrm{C}\right)$ to the research facilities. Representative samples (approximately $\left.50-100 \mathrm{~g}\right)$ of these muscles were then taken (approx $30 \mathrm{~h}$ post-mortem) and used for the determination of cooking loss and drip loss (Honikel, 1998; Van Schalkwyk et al., 2005). Due to unavoidable mechanical problems with the Instron, shear values were not determined on all samples. The colour of the fresh meat was evaluated after a blooming period of $30 \mathrm{~min}$ at an ambient temperature of $<8{ }^{\circ} \mathrm{C}$ in triplicate for each sample at randomly selected positions, by using a hand-held Gardner Colorimeter in order to determine CIELab L*, a* and b* values, indicating brightness, the red-green range and the blue-yellow range, respectively.

The results were analysed as a 2 X 2 X 2 factorial, the factors being electrical stimulation, sticking and sex. Least squares procedures were used since the distribution of sexes was unbalanced (25 males and 35 females were included in the experiment). Two-factor interactions were computed, but these were not significant in most cases. Main effect means were thus tabulated throughout, and the results of significant two-factor interactions are given in the text where applicable.

In the 32 carcasses used for the determination of $\mathrm{pH}$ profiles for the fillet and big drum, repeated $\mathrm{pH}$ and temperature recordings were analysed as a 2 (None vs. ES) X 2 (none vs. TS) X 8 (time of recording: 20, 140, 260, 380, 560, 680, 860 and 1440 min post mortem) factorial design. The random effect of carcass identity was included in these analyses, to account for the repeated sampling of the same experimental unit. It was assumed that the inclusion of the between animal variance component would account for the repeated measurements on the same animal. It had the added advantage that an estimate of repeatability could be computed for $\mathrm{pH}$ and temperature in these animals.

\section{Results and Discussion}

Live weight at the abattoir was unaffected by gender whilst the thigh weight was also unaffected by both treatments (electrical stimulation or sticking) and gender (Table 1). Cooking loss and drip loss of the fillet, loin and big drum muscles were also generally independent of ES or bleeding method (Table 1). The exceptions were cooking loss in the fillet muscle, which were slightly lower $(\mathrm{P}<0.05)$ in the TS group than in the control (exsanguination alone) group. Males also had higher $(\mathrm{P}<0.01)$ values than females for drip loss in the big drum. It is well known that muscle $\mathrm{pH}$ post mortem influences the water-holding capacity of meat and that high ultimate $\mathrm{pH}$ contribute to higher water-holding capacity and a lower drip loss (Lawrie, 1998). In the present study, although not significant $(\mathrm{P}>0.05)$, the $\mathrm{pH}$ at slaughter and after $24 \mathrm{~h}$ were lower in the big drum muscle for the males as compared to the females (Table 3). This may have been partly the cause for the higher drip loss ( $\mathrm{P} \leq 0.01)$ recorded for the big drum in the males as compared to the females. Drip loss in the loin samples also tended $(\mathrm{P}=0.07)$ to be slightly lower in the TS group than in control birds. No differences $(\mathrm{P}<0.05)$ were found for any of the treatments in the shear values of the fillet muscle. In a study on chickens, Devine et al. (2001b) found that the rate of post mortem pH decline was accelerated in ES birds and that these went into rigor at 120 min post stun whilst non ES birds took $300 \mathrm{~min}$. The ES muscles were also more tender. However, Soniya et al. (1982) found that where electrical stimulation caused a rapid $\mathrm{pH}$ decline ( $\mathrm{pH}<5.9$ at $3 \mathrm{~h}$ post-stimulation) in cow carcasses, no significant reduction in shear force could be found between stimulated and non-stimulated carcasses. Devine et al. (2001a) also found that ES resulted in ovine muscles going into rigor mortis earlier and at a slightly higher temperature than un-stimulated carcasses; however, ES did not result in more tender meat. In a later study on a larger group of lambs, Devine et al. (2006) found that ES resulted in more tender meat, a result more consistent with others (as reviewed by Simmons et al., 2008).

No differences $(\mathrm{P}<0.05)$ attributable to either of the treatments or gender could be detected in the colorimetric values recorded on fillet, loin or big drum samples (Table 2). Measurements of the $b^{*}$ values in 
Table 1 Least squares means ( \pm s.e.) for ostrich live and drumstick weights, cooking loss and drip loss of fillet, loin and big drum samples, as affected by the main effects of electrical stimulation, sticking and gender

\begin{tabular}{|c|c|c|c|c|c|c|}
\hline \multirow{2}{*}{$\begin{array}{l}\text { Cooking or drip } \\
\text { loss (\%) }\end{array}$} & \multicolumn{2}{|c|}{ Electrical stimulation } & \multicolumn{2}{|c|}{ Sticking } & \multicolumn{2}{|c|}{ Gender } \\
\hline & No & Yes & No & Yes & Male & Female \\
\hline $\begin{array}{l}\text { Number of } \\
\text { observations }\end{array}$ & 15 & 15 & 15 & 15 & 25 & 35 \\
\hline $\begin{array}{l}\text { Live weight at } \\
\text { abattoir }\end{array}$ & $96.3 \pm 0.7$ & $97.4 \pm 0.7$ & $96.3 \pm 0.7$ & $97.4 \pm 0.7$ & $96.8 \pm 0.8$ & $96.9 \pm 0.6$ \\
\hline $\begin{array}{l}\text { Drumstick } \\
\text { weight }\end{array}$ & $20.6 \pm 0.5$ & $21.7 \pm 0.5$ & $21.4 \pm 0.5$ & $20.9 \pm 0.6$ & $21.2 \pm 0.6$ & $21.2 \pm 0.5$ \\
\hline \multicolumn{7}{|l|}{ Cooking loss } \\
\hline Fillet & $28.6 \pm 0.4$ & $27.9 \pm 0.4$ & $28.9^{\mathrm{b}} \pm 0.4$ & $27.7^{\mathrm{a}} \pm 0.4$ & $27.9 \pm 0.5$ & $28.7 \pm 0.4$ \\
\hline Inside loin & $23.7 \pm 0.6$ & $23.3 \pm 0.6$ & $23.8 \pm 0.6$ & $23.1 \pm 0.6$ & $23.3 \pm 0.7$ & $23.6 \pm 0.5$ \\
\hline Big drum & $25.3 \pm 0.5$ & $25.0 \pm 0.5$ & $25.6 \pm 0.5$ & $24.7 \pm 0.5$ & $25.3 \pm 0.5$ & $25.0 \pm 0.4$ \\
\hline \multicolumn{7}{|l|}{ Drip loss } \\
\hline Fillet & $2.16 \pm 0.24$ & $2.11 \pm 0.26$ & $2.33 \pm 0.24$ & $1.94 \pm 0.27$ & $2.27 \pm 0.28$ & $2.01 \pm 0.23$ \\
\hline Inside loin & $1.57 \pm 0.21$ & $1.07 \pm 0.23$ & $1.61 \pm 0.21$ & $1.02 \pm 0.23$ & $1.53 \pm 0.24$ & $1.10 \pm 0.20$ \\
\hline Big drum & $0.56 \pm 0.04$ & $0.63 \pm 0.04$ & $0.63 \pm 0.04$ & $0.55 \pm 0.04$ & $0.67^{1} \pm 0.04$ & $0.51^{2} \pm 0.03$ \\
\hline $\begin{array}{l}\text { Fillet shearing } \\
\text { value (N/1.27 cm } \\
\text { diameter) }\end{array}$ & $95 \pm 6$ & $102 \pm 5$ & $97 \pm 6$ & $100 \pm 5$ & $103 \pm 6$ & $94 \pm 8$ \\
\hline
\end{tabular}

the big drum muscle of individuals subjected to the TS treatment tended $(\mathrm{P}=0.10)$ to be slightly higher (more towards yellow) than those of their control group contemporaries. In the case of a* measurements made on the loin samples, interpretation was complicated by an interaction $(\mathrm{P}<0.05)$ between gender and electric stimulation. Carcasses of male birds that were subjected to the ES treatment tended to have higher values than control animals $(15.0 \pm 0.5$ vs. $14.2 \pm 0.4$, respectively). A TS treatment difference $(\mathrm{P}<0.05)$ in the opposite direction was found in females $(13.7 \pm 0.4$ vs. $14.8 \pm 0.4)$. A corresponding gender*ES treatment interaction $(\mathrm{P}<0.06)$ was observed in the $\mathrm{b}^{*}$ measurement of the big drum samples. Carcasses of male birds subjected to ES treatment tended to have higher values than those of control animals $(9.7 \pm 0.5 \mathrm{vs}$. $9.4 \pm 0.4$, respectively). A treatment difference $(\mathrm{P}<0.05)$ in the opposite direction was found in females $(8.9$ \pm 0.4 vs. $10.7 \pm 0.4)$.

Electrical stimulation resulted in lower $(\mathrm{P}<0.05) \mathrm{pH}$ measurements in the fillet and the big drum muscles immediately after slaughter (Table 3). However, after $24 \mathrm{~h}$, a reversed tendency $(\mathrm{P}<0.10)$ was found towards higher $\mathrm{pH}$ measurements only in the big drum of carcasses subjected to the ES treatment. Electrical stimulation also resulted in elevated temperatures $\left(>4^{\circ} \mathrm{C}\right)$ immediately after slaughter, both in the fillet and big drum muscles, a phenomenon also noted by Devine et al. (2001a). This increase in temperature can be directly attributed to the muscle contraction caused by the ES. Although the final temperature of the big drum muscle was significantly $(\mathrm{P}<0.05$ ) lower in carcasses subjected to ES (Table 3), this difference is of little practical implication as all the muscle temperatures were $<1.0^{\circ} \mathrm{C}$ indicating an efficient cooling regime. The only consistent effect of electrical stimulation was therefore a reduction in initial muscle $\mathrm{pH}$, and an increase in the initial muscle temperature. No consistent differences between treatments were present by $24 \mathrm{~h}$ post mortem. The present research therefore supported the observations of Morris et al. (1995) that electrical stimulation did not substantially contribute to the ultimate $\mathrm{pH}$ or temperature decline in ostrich meat.

Thoracic sticking did not exert a marked influence $(\mathrm{P}<0.05)$ on $\mathrm{pH}$ and temperature measurements, except for the initial temperature of the big drum muscle, where it was higher in the TS group (Table 4) - the reason for this phenomenon is unclear. Temperature and $\mathrm{pH}$ measurements were unaffected by gender at all stages and in all muscles. 
Table 2 Least squares means ( \pm s.e.) for colorimetric parameters ( $\mathrm{L}^{*}, \mathrm{a}^{*}$ and $\mathrm{b}^{*}$ ) of fillet, loin and drumstick samples, as affected by the main effects of electrical stimulation, sticking and gender

\begin{tabular}{|c|c|c|c|c|c|c|}
\hline \multirow{2}{*}{$\begin{array}{l}\text { Muscle and } \\
\text { measurement }\end{array}$} & \multicolumn{2}{|c|}{ Electrical stimulation } & \multicolumn{2}{|c|}{ Sticking } & \multicolumn{2}{|c|}{ Gender } \\
\hline & No & Yes & No & Yes & Male & Female \\
\hline \multicolumn{7}{|c|}{ Fillet (M. iliofibularis) } \\
\hline $\mathrm{L}^{*}$ & $39.3 \pm 0.4$ & $39.7 \pm 0.4$ & $39.5 \pm 0.4$ & $39.5 \pm 0.4$ & $39.6 \pm 0.4$ & $39.4 \pm 0.3$ \\
\hline$a^{*}$ & $12.8 \pm 0.3$ & $12.3 \pm 0.3$ & $12.5 \pm 0.3$ & $12.6 \pm 0.3$ & $12.7 \pm 0.3$ & $12.4 \pm 0.3$ \\
\hline $\mathrm{b}^{*}$ & $9.2 \pm 0.3$ & $9.4 \pm 0.3$ & $9.3 \pm 0.3$ & $9.3 \pm 0.3$ & $9.3 \pm 0.3$ & $9.3 \pm 0.3$ \\
\hline \multicolumn{7}{|c|}{ Inside loin (M. iliotibialis cranialis) } \\
\hline $\mathrm{L}^{*}$ & $39.3 \pm 0.4$ & $39.7 \pm 0.4$ & $39.5 \pm 0.4$ & $39.5 \pm 0.4$ & $39.6 \pm 0.4$ & $39.4 \pm 0.3$ \\
\hline$a^{*}$ & $12.8 \pm 0.3$ & $12.3 \pm 0.3$ & $12.5 \pm 0.3$ & $12.6 \pm 0.3$ & $12.7 \pm 0.3$ & $12.4 \pm 0.3$ \\
\hline$b^{*}$ & $9.2 \pm 0.3$ & $9.4 \pm 0.3$ & $9.3 \pm 0.3$ & $9.3 \pm 0.3$ & $9.3 \pm 0.3$ & $9.3 \pm 0.3$ \\
\hline \multicolumn{7}{|c|}{ Big drum (M. gastrocnemius, pars interna) } \\
\hline $\mathrm{L}^{*}$ & $37.8 \pm 0.4$ & $37.1 \pm 0.4$ & $37.7 \pm 0.4$ & $37.1 \pm 0.5$ & $37.5 \pm 0.5$ & $37.4 \pm 0.4$ \\
\hline$a^{*}$ & $13.6 \pm 0.3$ & $13.5 \pm 0.3$ & $13.2 \pm 0.3$ & $13.9 \pm 0.3$ & $13.6 \pm 0.3$ & $13.5 \pm 0.2$ \\
\hline$b^{*}$ & $10.0 \pm 0.3$ & $9.3 \pm 0.3$ & $9.9 \pm 0.3$ & $9.4 \pm 0.3$ & $9.5 \pm 0.3$ & $9.8 \pm 0.3$ \\
\hline
\end{tabular}

Table 3 Least squares means ( \pm s.e.) for $\mathrm{pH}$ and temperature, as measures at slaughter and after $24 \mathrm{~h}$ in the fillet and drumstick samples, as affected by the main effects of electrical stimulation, sticking and gender

\begin{tabular}{lcccccc}
\hline \multirow{2}{*}{$\begin{array}{l}\text { Muscle and } \\
\text { measurement }\end{array}$} & \multicolumn{2}{c}{ Electrical stimulation } & \multicolumn{2}{c}{ Sticking } & \multicolumn{2}{c}{ Gender } \\
\cline { 2 - 7 } & No & Yes & No & Yes & Male & Female \\
\hline $\begin{array}{l}\text { Fillet (M. iliofibularis) } \\
\text { pH }\end{array}$ & & & & & \\
$\quad 45$ min post stun & $5.75^{\mathrm{a}} \pm 0.02$ & $5.67^{\mathrm{b}} \pm 0.02$ & $5.70 \pm 0.02$ & $5.72 \pm 0.02$ & $5.71 \pm 0.02$ & $5.71 \pm 0.02$ \\
$\quad$ After 24 h & $5.88 \pm 0.02$ & $5.90 \pm 0.02$ & $5.91 \pm 0.02$ & $5.88 \pm 0.02$ & $5.89 \pm 0.02$ & $5.89 \pm 0.01$ \\
Temperature & & & & & & \\
$\quad$ 45 min post stun & $33.7^{1} \pm 0.6$ & $37.9^{2} \pm 0.6$ & $35.3 \pm 0.6$ & $36.4 \pm 0.6$ & $35.7 \pm 0.7$ & $35.9 \pm 0.5$ \\
$\quad$ After 24 h & $0.61 \pm 0.06$ & $0.64 \pm 0.06$ & $0.59 \pm 0.05$ & $0.66 \pm 0.07$ & $0.65 \pm 0.08$ & $0.60 \pm 0.04$ \\
Big drum (M. gastrocnemius, pars interna) & & & & & \\
pH & & & & & \\
$\quad$ 45 min post stun & $6.21^{2} \pm 0.04$ & $6.01^{1} \pm 0.05$ & $6.08 \pm 0.04$ & $6.14 \pm 0.05$ & $6.09 \pm 0.05$ & $6.13 \pm 0.04$ \\
$\quad$ After 24 h & $5.85 \pm 0.02$ & $5.92 \pm 0.03$ & $5.86 \pm 0.02$ & $5.91 \pm 0.03$ & $5.87 \pm 0.03$ & $5.90 \pm 0.02$ \\
Temperature & & & & & \\
$\quad$ 45 min post stun & $31.1^{1} \pm 0.4$ & $35.8^{2} \pm 0.4$ & $31.9^{1} \pm 0.4$ & $35.0^{2} \pm 0.4$ & $33.7 \pm 0.5$ & $33.2 \pm 0.4$ \\
$\quad$ After 24 h & $0.74^{\mathrm{b}} \pm 0.03$ & $0.64^{\mathrm{a}} \pm 0.04$ & $0.66 \pm 0.03$ & $0.72 \pm 0.04$ & $0.64 \pm 0.74$ & $0.74 \pm 0.02$ \\
\end{tabular}

${ }^{\mathrm{a}, \mathrm{b}}$ Row means with common superscripts differ significantly at $\mathrm{P} \leq 0.05$.

${ }^{1,2}$ Row means with common superscripts differ significantly at $\mathrm{P} \leq 0.01$.

When the influence of TS on the post mortem $\mathrm{pH}$ changes in both the fillet and big drum muscles were considered, it was evident than neither TS treatment $(\mathrm{P}>0.25)$ nor its interaction with time post mortem $(\mathrm{P}$ $>0.10)$ reached statistical significance. The significant $(\mathrm{P}<0.05)$ initial $\mathrm{pH}$ difference between birds subjected to the ES treatment relative to the control (Table 3) was reduced to a tendency with the smaller data set used for the $\mathrm{pH}$ profiles (5.68 \pm 0.02 vs. $5.72 \pm 0.02$, respectively; $\mathrm{P}<0.10$ ). No overall effect of ES ( $\mathrm{P}>0.50)$ or the ES*time interaction $(\mathrm{P}=0.23)$ was evident from the data. The $\mathrm{pH}$ of the fillet muscle generally increased with time post mortem (Figure 1). No further increase was observed after 800 min post 
mortem. This increase in pH observed in the fillet has been documented previously (Botha et al., 2006; 2008; Hoffman et al., 2007). In fact, Hoffman et al. (2007) showed that ostrich fan fillet muscle does have an initial $\mathrm{pH}$ decrease that occurred within the first 30 - 40 min post mortem, where after the muscle $\mathrm{pH}$ started increasing again. A phenomenon that requires further research as it is still not explained.

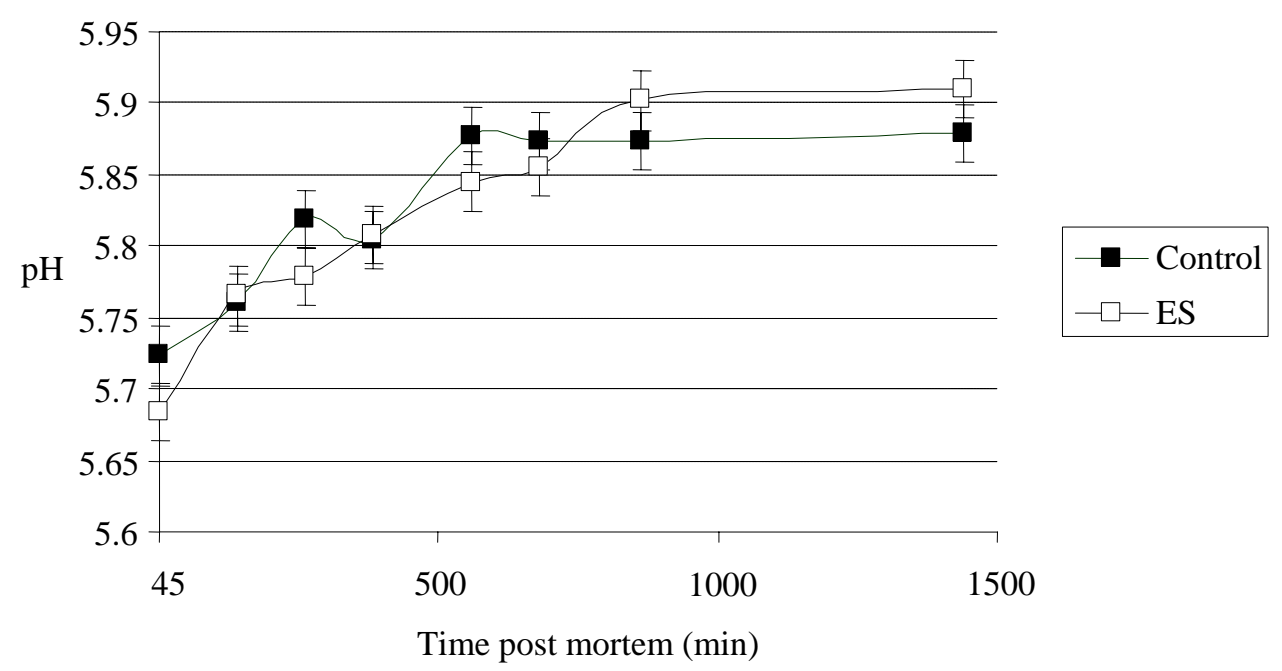

Figure 1 Trends in the $\mathrm{pH}$ of the fillet muscle (M. iliofibularis) of ostrich carcasses subjected to electrical stimulation and untreated controls over time. Vertical lines about the means represent standard errors.

Overall, the observed $\mathrm{pH}$ of the big drum muscle was unaffected by the ES treatment $(\mathrm{P}=0.11)$. However, the ES treatment interacted with time post mortem $(\mathrm{P}<0.01)$. The interaction was caused by a reduced $\mathrm{pH}$ in the big drum muscle in ES treated carcasses shortly after slaughter (20 and 140 min post mortem), while no further effect of ES was evident at later stages (Figure 2). As a matter of fact, the order was reversed by $24 \mathrm{~h}$ after slaughter. At this stage, the $\mathrm{pH}$ values of ES treated carcasses tended to be higher than those of control carcasses $(\mathrm{P}<0.10)$, as was also noted in Table 3.

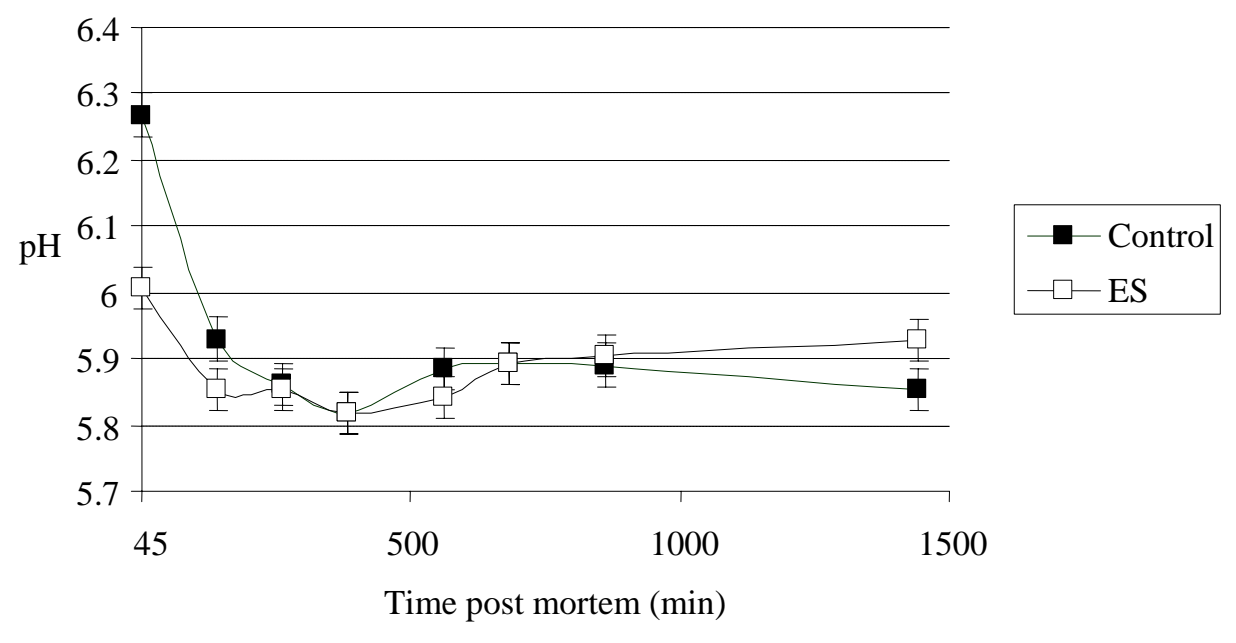

Figure 2 Trends in the $\mathrm{pH}$ of the big drum muscles (M. gastrocnemius, pars interna) of ostrich carcasses subjected to electrical stimulation and untreated controls over time. Vertical lines about the means represent standard errors.

The derived repeatability estimates ( \pm s.e.) for $\mathrm{pH}$ amounted to $0.33 \pm 0.08$ for the fillet muscle and to $0.06 \pm 0.05$ for the big drum muscle. The corresponding estimates for temperature were respectively 0.33 \pm 0.07 and $0.43 \pm 0.08$. 


\section{Conclusions}

The main effect, ES, resulted in higher temperatures and accelerated $\mathrm{pH}$ decline immediately after slaughter in both the fillet and big drum muscles. Electrical stimulation, however, had no significant effect on shear force values post mortem for the fillet muscle. There was also no significant difference in cooking loss and drip loss between the ES and non-ES treated carcasses for the three muscles that were investigated.

The main effects, ES, TS, and gender, had no significant effects on colorimetric values for the three muscles investigated. Data indicated a significant TS effect on cooking loss for the fillet but not for the other two muscles (inside loin and big drum) investigated. Since no scientific explanation could be found for this effect, it was accepted that in the case of a larger sampling size, this effect will be statistically insignificant.

It can thus be concluded that there seems to be no positive or negative effect on any of the physical meat quality attributes evaluated with ES on ostriches. However, these results may be confounded by other factors such as ante mortem stress (Devine et al., 2006), the fact that electrical stunning was applied (Devine et al., 1984), the inherent high and rapid change in ostrich muscle $\mathrm{pH}$. Another factor that may have influenced the end result, or lack thereof, is the fact that only one set of ES parameters were evaluated and it has been well documented that different parameters (voltage, duration, pulse width/frequency, etc.) all contribute to the post mortem changes in muscle. Further research is required on ES using different stimulation parameters and more information/recordings should be collected on these effect using additional measurements such as sarcomere length, myofibre fragmentation, etc. More data on the effect of ES on the other important muscles (such as the Big Drum) is also required.

Although thoracic sticking combined with a ventral throat cut had no effect on these same physical attributes, personal observation on the slaughter line seem to indicate that the birds die more rapidly with the faster bleed-out experienced with thoracic sticking. This observation and the tendency towards a better bleed out percentage (as measured in the pilot study) experienced warrants further investigation as the former has an impact on the ethical slaughter of the birds, while the latter could have an influence on the shelf-life (bacterial growth) of the meat products.

\section{References}

Botha, S.St.C., Hoffman, L.C. \& Britz, T.J., 2004a. Muscle pH and temperature changes in ostrich M. iliofibularis and M. gastrocnemius, pars interna during the first $24 \mathrm{~h}$ post-mortem. In: Proc. $2^{\text {nd }}$ Joint Cong. Grassl. Soc. Southern Afr. \& S. Afr. Soc. Anim. Sci. 28 June-1 July 2004. Goudini, South Africa. p.152.

Botha, S.St.C., Hoffman, L.C., Britz, T.J. Nilsen, B.N. \& Slinde, E., 2004b. The effect of rigor-temperature on isometric tension, shortening and $\mathrm{pH}$ for ostrich M. gastrocnemius, pars interna. In: Proc. $50^{\text {th }}$ Int. Congr. Meat Sci. Techn. August 2004. Helsinki, Finland. p. 74.

Botha, S.St.C, Hoffman, L.C. \& Britz, T.J., 2006. Effect of hot-deboning on the physical quality characteristics of ostrich meat. S. Afr. J. Anim. Sci. 36, 197-208.

Botha, S.St.C., Hoffman, L.C. \& Britz, T.J., 2008. Effects of post mortem temperature on rigor tension, shortening and $\mathrm{pH}$ in ostrich muscle. S. Afr. J. Anim. Sci. 38, 184-192.

den Hertog-Meischke, M.J., Smulders, F.J., Van Logtestijn, J.G. \& Van Knapen, F., 1997. The effect of electrical stimulation on the water-holding capacity and protein denaturation of two bovine muscles. J. Anim. Sci. 75, 118-124.

Devine, C.E., Ellery, S., Wade, L. \& Chrystall, B.B., 1984. Differential effects of electrical stunning on the early post mortem glycolysis in sheep. Meat Sci. 11, 301-309.

Devine, C.E., Wells, R., Cook, C.J. \& Payne, S.R., 2001a. Does high voltage electrical stimulation of sheep affect rate of tenderization? N. Z. J. Agric. Res. 44, 53-58.

Devine, C.E., Wild, D.J.C. Cummings, T.L. \& Reed, H., 2001b. Factors affecting tenderness of electricallystimulated poultry. N. Z. J. Agric. Res. 44, 169-173.

Devine, C.E., Lowe, T.E., Wells, R.W., Edwards, N.J., Hocking Edwards, J.E., Starbuck, T.J. \& Speck, P., 2006. Preslaughter stress arising from on-farm handling and its interactions with electrical stimulation on tenderness of sheep. Meat Sci. 73, 304-312.

Hector, D.A., Brew-Graves, C., Hassen, N. \& Ledward, D.A., 1992. Relationship between myosin denaturation and the colour of low-voltage-electrically stimulated beef. Meat Sci. 31, 299-307. 
Hoffman, L.C., 2005. A review of the research conducted on ostrich meat. In: Proc. $3^{\text {rd }}$ Int. Ratite Sci. Symp. \& XII Wrld Ostr. Congr'. pp. 107-119.

Hoffman, L.C., Botha, S.St.C. \& Britz, T.J., 2007. Muscle pH and temperature changes in hot- and colddeboned ostrich (Struthio camelus var. domesticus) Muscularis gastrocnemius, pars interna and Muscularis iliofibularis during the first 23 h post mortem. Meat Sci. 75, 353-359.

Honikel, K.O., 1998. Reference methods for the assessment of physical characteristics of meat. Meat Sci. 49, 447-457.

Hwang, I.H., Devine, C.E. \& Hopkins, D.L., 2003. The biochemical and physical effects of electrical stimulation on beef and sheep meat tenderness. Meat Sci. 65, 677-691.

Lawrie, R.A.. 1998. The storage and preservation of meat 1. Temperature Control. Meat Science. $6^{\text {th }}$ ed., New York: Pergamon Press. pp. 147-177.

McGlone V.A, Devine, C.E. \& Wells, R.W., 2005. Detection of tenderness, post rigor age and water status changes in sheep using near infrared spectroscopy. J. N. Infra. Spectr. 13, 277-285

Martin, A.H., Murray, A.C., Jeremiah, L.E. \& Dutson, P.J., 1983. Electrical stimulation and carcass aging effects on beef carcasses in relation to post-mortem glycolytic rates. J. Anim. Sci. 57, 1456-1462.

Morris, C.A., Harris, S.D., May, S.G., Jackson, T.C., Hale, D.S., Miller, R.K., Keeton, J.T., Acuff, G.R., Lucia, L.M. \& Savell, J.W., 1995. Ostrich slaughter and fabrication. 1. Slaughter yields of carcasses and effects of electrical stimulation and post-mortem pH. Poult. Sci. 74, 1683-1687.

Offer, G. \& Trinick, J., 1983. On the mechanism of water holding in meat, the swelling and shrinking of myofibrils. Meat Sci. 8, 245-281.

Pearson, A.M. \& Young, R.B., 1989. Post-mortem changes during conversion of muscle to meat. In: Food Science and Technology, Muscle and Meat Biochemistry. Eds Schweigert, B.S. \& Taylor, S.L., New York: Academic Press, Inc. pp. 391-425.

Rosenvold, K., North, M., Devine, C.E., Micklander, E., Hansen, P., Dobbie, P. \& Wells, R., 2008. The protective effect of electrical stimulation and wrapping on beef tenderness at high pre-rigor temperatures. Meat Sci. 79, 299-306

Sales, J. \& Mellett, F.D., 1996. Post-mortem pH decline in different ostrich muscles. Meat Sci. 42, 235-238.

Simmons, N.J., Daly, C.C., Cummings, T.M., Morgan, S.K., Johnson, N.V. \& Lombard, A., 2008. Reassessing the principles of electrical stimulation. Meat Sci. 80, 110-122.

Sleper, P.S., Hunt, M.C., Kropf, D.H., Kastner, C.L. \& Dikeman, M.E., 1983. Electrical stimulation effects on myoglobin properties of bovine longissimus muscle. J. Fd Sci. 48, 479-483.

Soniya, E.B., Stouffer, J.R. \& Beerman, D.H., 1982. Electrical stimulation of mature cow carcasses and its effect on tenderness, myofibril protein degradation and fragmentation. J. Fd Sci. 47, 889-891.

Stiffler, D.M., Griffin, C.L., Smith, G.C., Lunt, D.K. \& Savell, J.W., 1986. Effects of electrical stimulation on carcass quality and meat palatability traits of Charolais crossbred bulls and steers. J. Fd Sci. 51, 883-885.

Taylor, A. \& Tantikov, M., 1992. Effect of different electrical stimulation and chilling treatments on pork quality. Meat Sci. 31, 381-396.

Van Schalkwyk, S.J., Hoffman, L.C., Cloete, S.W.P. \& Mellett, F.D., 2005. The effect of feed withdrawal during lairage on meat quality characteristics in ostriches. Meat Sci. 69, 647-651.

Van Schalkwyk, S.J., Cloete, S.W.P. \& De Kock, J.A., 1996. Repeatability and phenotypic correlations for live weight and reproduction in commercial ostrich breeding pairs. Br. Poult. Sci. 37, 953-962.

Wiklund, E., Stevenson-Barry, J.M., Duncan, S.J. \& Littlejohn, R.P., 2001. Electrical stimulation of red deer (Cervus elaphus) carcasses - effects on rate of $\mathrm{pH}$-decline, meat tenderness, colour stability and waterholding capacity. Meat Sci. 59, 211-220.

Wu, F.Y., Dutson, T.R., Valin, C., Cross, H.R. \& Smith, S.B., 1985. Aging index, lysosomal enzyme activities, and meat tenderness in muscle from electrically stimulated bull and steer carcasses. J. Fd Sci. 50, 1025-1028. 